\title{
健診と CT
}

田近明男

成人病健診の検査の柱として，X線検査は被曝という デメリットにあかかわらず，不可欠のあのである。X線 $\mathrm{CT}$ 検査となると被曝むさることながら，ルーチン検査 の範囲外として自動化健診の中では登場してきていない が, 病変の存在診断の手段として非観血的により多くの 情報が得られるととを考慮して昭和 62 年 9 月に同一健 診フロアー内にX線 CT 装置（東芝製 TCT-300）を設 置した。

昭和 63 年 1 月から 12 月までの 1 年間に 419 例の CT 検査を実施してきた。検査部位別では頭部 89 例, 胸部 93 例, 膵臓 126 例, 肝臟 29 例, 脾㵴 1 例, 腎臟 36 例, 膀胱 4 例, 胆のう 14 例, 子宮 6 例, 卵巣 3 例, その他 18 例である。当センターでは腹部超音波検查は全員必須 検査項目となっているので, 腹部臓器の CT は殆んど超 音波検査での有所見例又は腸ガスの為，検查不充分であ った場合が多いが，日を改めて精密検査として CT を実 施した。

実施にあたりエンハンスしないプレーンCT のみを原 則とし，一番実施例の多かった膵蔵に関してはガストロ グラフィンを約 $2 \%$ に希釈して $300 \mathrm{cc}$ 飲ませ, 10 分後 から検査開始を原則とした。これは膵頭部とそれを取り まくように走行する十二指腸下行脚との識別を容易にす る為である。

エンハンス CT までするべきかが問題となり，エン ハンスしなければ描出できない疾患屯懸念されるが，健 康な人を対象とした健診の場ではヨード系造影剂の静注 による重篤なショック状態の危険も無視することが出来 ず，とりあえず，暗中模索のうちにエンハンスしないプ レーン CT のみ実施してきている。プレーン CT の結
果，さらにエンハンスの必要ありとなったケースには救 命救急設備の整った施設で行なうのが妥当と考えられ る。

腹部 CT 検査は上部消化管検查で使用したバリウム 等の造影剂が排泄されるまでは，アーチファクトが出る 為, 検査出来ませんが，頭部，胸部の CT についてはバ リウムと関係なく同じ日に CT 検査可能であります。そ こで健診当日に，頭部 CT 39 例（これは全頭部 CT の 約 44\%), 胸部 CT 39 例（これは全胸部 CT の 42\%） の合計 78 例を追加 $\mathrm{CT}$ 検査としてバリウムを飲んだ後 で実施している。

昭和 63 年 1 月から 12 月までに, 定期健診で肺疾患が 疑がわれ，当センターでの胸部 CT 検査がきっかりと なり, 紹介先病院で肺癌之確定されたものは 4 症例であ る。 4 症例と屯定期健竝後, 比較的短加期間で $\mathrm{CT}$ 検 查を終え，全例とあスムースに手術に持ち込むことが出 来た。

受診者にとって健診の魅力の一つが「短時間に広い範 囲のチェックが受けられ，すぐに結果が聞ける」という 点にあるのは歪めない。

このととを考慮し，従来は後日他の施設へ紹介して来 た CT 検査を自施設で即日行なえるよう，CT 装置を健 診センター内に設置して, 診断限界を拡げる努力をした。

ランニングコスト面など，予想した問題はあるが, CT を手近かに持つことのメリットがそれを上回るかど うかは，実際に使って見ねば分らぬと思われ，敢えて導 入に踏み切って, 現在両者の兼极合いを模索している段 階である。

\footnotetext{
Disease Detection Coverage of AMHT Widened by Adding CT

PL 大阪健康管理センター
} 